\title{
Study on the English Picture-book Reading Promotion Strategies: Taking the Anniekids English library as an Example
}

\author{
Honglei Wang \\ College of Foreign Studies \\ Shandong Technology and Business University \\ Yantai, China
}

\begin{abstract}
The effective way to promote children's English picture-book reading is to keep children in the dominant position no matter in the process of choosing or reading books. Meanwhile, proper and scientific guidance is necessary for effective parent-child reading due to the important role parents play in children's English reading. Multiple language activities and user-friendly service of the library are also important to promote this reading.
\end{abstract}

\section{Keywords—children; English reading; English Picture-book}

\section{INTRODUCTION}

Picture book which is characterized by the complement of image and text and exquisite design is recognized as the most suitable for children. With simple text, picture books reflect the daily life scenes in an artistic and interesting way, which appeals to the physiological and psychological characteristics of the children. In addition, foreign picture books started earlier and are more mature. Guiding children to read interesting and attractive original picture books serves multiple ends. It not only inspires children's mind, but also helps them absorb the original language with ease and pleasure. And more importantly, it protects children's interest in language learning.

\section{DifficUlties IN THE PROMOTION OF PICTURE- BOOK READING}

Although more and more attention has been paid to English picture-book reading, there are still some difficulties and misunderstandings in its operation and promotion.

\section{A. Benefiting only a Few}

At present, only a few public libraries in big cities have introduced children's English original books. Civilian English book library is far from universal, and because of its dear charges, is still a kind of extravagant consumption. As a result, children in most areas have no access to English original books Not only that, original books are generally expensive, so it is difficult to achieve the goal of reading extensively only by family investment and may cause a big waste of resources. Therefore, there are only a few children who have the opportunity to get the original English reading.

\section{B. Lack of Professional Guidance}

The particularity of English reading determines the difficulty of family practice. From the choice of reading materials to the guidance and instruction of reading, all of them need professional knowledge. For children who have just come into contact with English, it is only through effective reading that the original reading can bring a sense of happiness and achievement. The reality is, faced with the vast original books, most parents do not know where to start to choose the right one Many parents do not have the knowledge of the original books for their children, or they are not confident in their English proficiency, which hinders the development of English reading. What's worse, there are few librarians who have specialized knowledge of books and reading knowledge in English to effectively guide parents and children to choose and read books Actually, professional librarians are the key to the promotion of children's English reading. They are responsible for the planning, implementation and publicity of promotional activities. Libraries usually have librarians who are in charge of specific children's English reading activities, but in reality, most librarians lack adequate English knowledge. Therefore, although children's English original reading is becoming more and more popular, there's far from enough specialized guidance in children's English reading.

\section{The Restriction of Current Education}

Since 1990, Taiwan has introduced a large number of picture books. It started early in the reading and writing of picture books, and has combined English original reading with English teaching. In mainland China, the exploration of English original reading in primary school has just begun. Our present teaching is still examination-oriented, and the grammar teaching mode that focuses on scores and neglects ability is still the mainstream. Parents and society also pay more attention to short-term effects. The original reading requires both patient guidance and long-term adherence. Extracurricular readings that do not immediately produce good scores are naturally excluded. Even large children's English libraries with resource advantages are faced with the plight of reading promotion. "A large proportion of school-age children are not even able to finish their homework, let alone spare time for the so-called light reading. The original books which are more difficult and time-consuming are rarely asked" [1] 
Therefore, how to scientifically promote English picturebook reading and help children with their English reading needs a lot of practice and extensive discussion. Because of the particularity of the children group, it is very important for parents to pay attention and participate, especially in the promotion of the scientific concept. Taking Anniekids English Library as an example, the advanced language learning concept and effective English reading experience provide valuable experience for the promotion of children's English reading.

\section{Less Promotional Activities}

By reading promotion activities, more children and parents can learn about the advantages and feasibility of English reading. At present, both public libraries and private training institutions rarely carry out English reading promotion activities for children. The limited number of reading activities are relatively simple, such as English corner, English class and salon. Children and parents are not really exposed to the original English reading, nor aware of its importance and interest.

In addition, the lack of reading resources and publicity also affected the promotion of English reading. Currently children's English reading resources are mainly paper and audio-visual resources. But in general, children's access to original reading resources is far from adequate. Effective and powerful publicity and reading promotion activities are important to make more readers know and accept original English reading.

\section{PutTing ChILdREN's InTEREST IN THE FIRST PlaCE}

The main part of children's English reading is children and their interests should be placed in the primary position, which is the first problem that should be clearly defined in children's reading activities. Then in the reading activities, it is essential to pay attention to children's initiative, to protect children's interest and nature, so that reading becomes something children take an active part in.

\section{A. Interest First in Choosing Books}

First of all, children's interest should be placed in the first placed in book choosing. Then provide children with reading materials that meet their cognitive level. Reading English in a Chinese context often involves obstacles, especially for children who already have basic Chinese knowledge. Therefore, whether they are guided scientifically in English reading is the key to success. Parents or teachers who are reading guides should try their best to stimulate and protect children's reading interest. If they ignore children's feelings and choose only what they think is good for them, forcing them to read, it will inevitably lead to children's rebellion and make reading difficult to carry on.

It is safe to come to the conclusion that children should be taken as the leading role and books should be picked according to their current interests. The practice of Anniekids English Library can serve as a good example. To choose the right books, the key is to observe and seize children's interests, and then provide as many books of related topics as possible for children to choose. It is also important to provide sufficient diversity of book resources to meet the children's cognitive level at each stage to ensure that children's reading ability improves in a spiral way. For example, the Anniekids English Library homepage offers a very helpful search method to classify and include all specific book themes, such as animal, family, adventures, art and music, social life, animated themes, bedtime stories, science and technology, sports, history, to name only a few. In addition, there are more than 20 special categories for boys and girls. Many of these categories are further subdivided. For example, the social class includes topics of the first experience, courtesy, team work, contact among opposite-sex peers, respect and responsibility, etc. [2].

\section{B. Enjoyment First during Reading}

The highest state of reading is a state of total absorption. Reading of this kind is the most enjoyable and beneficial. Most Chinese people care a lot about their children's English learning, and many schools and training institutions are paying more and more attention to English reading which, however, is mostly for utilitarian purposes, violating language rules and ignoring children's nature. Because the traditional English reading is the so-called reading comprehension which emphasizes answering questions, getting the correct answer, and improving scores. Traditional reading comprehension is clearly a headache for children, because they can hardly enjoy the beauty of language or the story itself. Instead, they have to guess what kind of questions will be asked to cope with. There's no reading pleasure at all because reading becomes a burden. Reading a story as a textbook with the purpose of answering questions correctly is not real reading. Such reading is not the source of children's happiness, and it is also not conducive to the improvement of children's reading ability. Socrates has a saying, "education is not a matter of indoctrination; it is a lighting of fire." To make reading a happy experience, we need to stimulate children's interest.

\section{EMPHASIZE PARENT-CHILD READING GUIDANCE}

At present, although reading promotion has achieved certain results, the popularization of books has exceeded the concern for the construction of reading ability.

\section{A. Choosing His Own Book}

The first step in developing reading ability is to choose the right reading materials. Besides interests, level of difficulty is another important factor to consider. Too difficult books not only make hard reading, but discourage children. Too simple books are not challenging enough, and help little in improving children's reading ability. The main buyers and borrowers of children's books are parents. The fact is, however, most parents are confused when choosing books and it is a pity that many books end up being shelved. In terms of book selection, two rules which are popular in North America can be followed: the Five Finger Rule and the I PICK principle [3].

According to the Five Finger Rule, the child should read out one page of a book and one finger is put up when the child meets a word he doesn't know. If five fingers are raised before the page is finished, it means the book is too difficult; if only one finger is raised or no finger is raised at all, the book is too simple then. the Five Finger Rule which is simple and practical, can effectively help parents solve the problem of choosing books. 
Compared to the Five Finger Rule, the I PICK principle is more specialized and scientific. "I" refers to the author of the book; PICK refers to "Purpose", "Interest", "Comprehend", and "Know". By this, it means the reader should ask these questions when choosing his book: Why should I choose this book? Am I interested in the subject of this book? Can I understand the contents of this book? Do I know most of the words in it? Guided by adults, the I PICK principle can help children achieve the goal of choosing their own books.

\section{B. Parent-child Reading}

Reading starts at home. To develop English reading smoothly in the Chinese environment, we must solve the problem of reading guidance. For the children who just start English learning, the best and most important English book is the picture book. Picture books are ideal for parent-child reading. But as to English parent-child reading, if the method is inappropriate, it is likely to create a fearful and unpleasant feeling in children. In this regard, Anniekids English Library provides us with valuable reference.

The first step is picture-reading. Parents can help their children understand the pictures using Chinese or body language to make the children enjoy the fun of the pictures. The purpose is to relax and eliminate the English alert. The second step is picture-English associating. After the first step of picture-reading, the children may get interested in the book and have a general understanding of the story, parents can remove Chinese auxiliary to relate the pictures with English words and phrases. The last step is to listen to the whole reading or listening to the audio. This reading method does not aim to achieve any reading level, but pay close attention to children's interests and response, so as to guide them step by step. This method does not require the full use of English, but it cannot be simply classified as "sandwich" English, because for children, it is meaningful only if the reading strategy conforms to their cognitive level. Otherwise it will only make English reading a frightening experience for them.

\section{Multiple Language ACtivities}

It is very necessary to adopt rich and varied activities so as to create a friendly reading atmosphere. In this way, it is easier to promote reading because children may feel relaxed and close to English books. All kinds of reading activities are carried out not only to make children feel fun, but also to enhance children's confidence in using English language, to strengthen communication and create a relaxed and active atmosphere.

As the saying goes, "Practice goes deeper than theoretic knowledge." It is especially true for children. Story-telling coupled with various activities, such as children's songs, drama, scene performance, handwork, etc., can effectively enhance children's reading interest, arouse their enthusiasm, and urge them to continue to study deeply.

Most children love handwork. By acting out a story in a picture book or reproducing a plot in a story under the guidance of a parent or teacher, children's ability of language association is greatly stimulated. For example, have the children to recreate the story with clay after telling the story Little Blue and Little Yellow; When reading the story Maisy Makes lemonade, find the materials like lemons, water and sugar and try to make the children experience the joy of making lemonade by themselves. By doing handwork and interactive games, children can better understand the story, and also experience the charm of the language.

\section{CONCLUSION}

We live in an information age. Technology makes immediate communication possible, which also helps reading promotion. It is a good choice to establish a website or web page for sharing English reading. Sharing is a kind of display, including live display and virtual display. Compared with the kind of face-to-face sharing, virtual sharing is a kind of sharing mode which is not limited by time and space.

Libraries and bookstores can establish their website to publicize and share their English promotion activities through video, pictures and text, so that more readers can learn about English reading and books. For example, Baobaobooks, a large and influential online English bookstore that sells original English picture books, organize various activities regularly to involve more families in English reading. Besides that, it has its professional English instructors who tell English stories and share on line by video with the readers. In this way, the instructors actually are demonstrating for all the parents the right way for parent-child English reading, which not only promotes its book sale, but also successfully promotes English reading, making more families know and love English reading.

In addition, there are actually many ways to share and interact with the readers, such as micro-blog, WeChat and QQ. They are all quick and immediate ways to interact with each other, and can serve as powerful means to promote English reading. Anniekids' WeChat Subscription post all kinds of articles about reading skills and knowledge and also publicize some reading activities. In a word, multiple ways of interaction and sharing can surely enhance the influence of children's English Reading Promotion activities.

To summarize, Tadashi Matsui, the father of Japanese picture books, points out that children should be surrounded by interesting books rather than books that parents think are useful to their children [4]. To sum up, two key factors should be considered for effective children's English reading promotion. One is interest. To put children's interest in the first place, and strive to provide children with more interesting books is the only way to guide them close to books and reading. Another is mothed. Respect the law of language and pay attention to parent-child reading which is guided by scientific methods is the key to achieve effective reading.

\section{REFERENCES}

[1] Wang Y.D.,Wang Y.X., "A Preliminary Study on English Reading Promotion Activities for Minors: Taking Ming-De English Children Library as an Example", [J]. Library Research, 2015,( 1) pp.62-66.

[2] http:www.anniekids.org

[3] Zheng X.M.,Wang M., English Enlightenment That Can't be Missed -English Route Map for Chinese Children,[M].Foreign Language Teaching and Research Press, 2011, pp.80-85.

[4] Tadashi Matsui, Seeds of Happiness,[M].Twenty-first Century press, 2013. 